\title{
ON TAX IMPLICATIONS OF THE ROBOTIFICATION
}

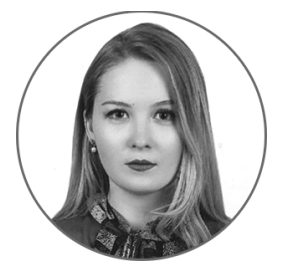

\author{
Elizaveta Ya. KAMARAEVA
}

Financial University under Government of Russian Federation, Moscow, Russian Federation elizabeth.kamaraeva@yandex.ru

Corresponding author

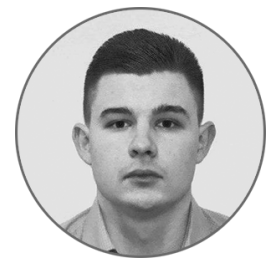

\section{Nikita A. MAKSIMOV}

Financial University under Government of Russian Federation, Moscow, Russian Federation nik-maksimov-97@mail.ru

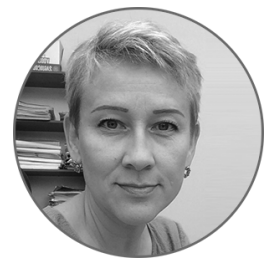

\section{Marina V. P'YANOVA}

Financial University under Government of Russian Federation, Moscow, Russian Federation marinapyanova@mail.ru

\section{Article history:}

Received 4 August 2017 Received in revised form 22 August 2017

Accepted 15 September 2017 Translated 26 September 2017 Available online 14 December 2017

JEL classification: $\mathrm{H} 20, \mathrm{H} 21, \mathrm{H} 25$

Keywords: robotification, tax implications, income loss, budget, robot tax, robotics

\begin{abstract}
Importance This article focuses on the robotification process and its impact on the budgetary system of the Russian Federation.

Objectives We scrutinize the situation in Russia in terms of the robotification extent in comparison with other countries, and determine taxes, which will be most impacted by robotification, and subsequent fiscal effects. We also analyze to what extent robotification threatens to social extrabudgetary funds, and estimate sales of robots in Russia, tax income loss, surplus tax revenue and losses of social extra-budgetary funds.

Methods Using the description and generalization, we identify strengths and weaknesses of global robotification processes. Based on extrapolation methods, analysis of statistical data, graphic method of data presentation, we obtain and report estimated sales of robots in Russia, income loss and surplus revenue of the budget, losses of social extrabudgetary funds as a result of the industrial robotification.

Results We quantify the robotification implications for the fiscal system of the Russian Federation and consider the possibility of introducing the robot tax.

Conclusions and Relevance The income loss will be offset by surplus income as a result of a growth in the corporate profit tax. We believe the Russian budget will soon have a significant burden as a result of the manpower substitution with robots. It will reduce fiscal revenue significantly due to transfers to extrabudgetary funds.
\end{abstract}

The editor-in-charge of this article was Irina M. Vechkanova Authorized translation by Irina M. Vechkanova 
Nowadays the robotification definitely turns into a natural process continuing worldwide within the span of several decades.

If viewed in the context of human development, the robotification opens up plenty of opportunities. The robotification automates the entire production process reducing the human factor as much as possible. Furthermore, robots ensure the uninterrupted production process. In other words, robots are free from any time constraints by work cycle [1]. It is worth mentioning that robotics gave a significant impetus to the development of medical knowledge. Currently, robots are involved in a great deal of complicated operations, and robotic prostheses help handicapped people live without routine physical challenges.

However, numerous benefits are accompanied with some implicit threats [2]. Manpower displacement appears to be the main negative implication triggering an unemployment growth. Moreover, market saturation and replacing humans with robots may make humans helpless, reluctant in their further development [3]. It is noteworthy that robots are not guided with any moral principles and responsibility, being incapable of substituting human beings but rather acting in a human-like manner ${ }^{1}$.

If viewed from perspectives of the State, the robotification is more negative than positive. After robots substitute people in productive and manufacturing processes, the budget will lose some portion of the withholding tax, VAT, social security charges, etc. [4] This fact unleashes multiple and recurring ideas of adopting a special tax on robots.

The legislative initiative of the robot tax was first presented in 2016 by Mady Delvaux, a member of the European Parliament from Luxembourg. According to Mady Delvaux, robots, bots, androids and other forms of artificial intelligence (AI) can invoke a new industrial revolution in the world [5].

${ }^{\dagger}$ For the source article, please refer to: Камараева Е.Я., Максимов Н.А., Пьянова М.В. О налоговых последствиях роботизации. Национальные интересы: приоритеты и безопасность. 2017. Т. 13. Вып. 9. С. 1608-1622. URL: https://doi.org/10.24891/ni.13.9.1608

${ }^{1}$ Sinitsyna Yu.V. [Problems of artificial intelligence and political challenges]. Molodezhnyi nauchno-tekhnicheskii vestnik, 2013, no. 5, p. 50. (In Russ.) URL: http://sntbul.bmstu.ru/doc/569262.html
Her bill sets out the following measures to assume control over the robotics development:

- registration of robots with migration authorities;

- legally imposed liability of machines for damage arising from the loss of live workplaces ${ }^{2}$;

- special taxes or social security charges to be paid by owners of robots;

- robot's subordination to its creator and incapability of inflicting any injury to people.

In February 2017, Bill Gates sounded a similar idea ${ }^{3}$. The founder of Microsoft Inc. suggested slowing down the speed of automation and replacing humans with robots through tax policies. As he sees it, robots and their labor should be subject to the withholding tax and social security charges. 'Right now, the human worker who does, say, \$50,000 worth of work in a factory, that income is taxed and you get income tax, social security tax, all those things. If a robot comes in to do the same thing, you'd think that we'd tax the robot at a similar level', Mr Gates opines. He also argues that income from the robot tax shall be used not only to offset the loss of tax revenue, but also support laid-up workers with lower income and retrain them. Therefore, money should be redirected from automated industries to socially important ones, where people cannot be substituted with robots (care about elderly people, children, etc.) [6].

However, neither Europe, nor the USA have any legislative regulation imposing the robot tax.

As for the adoption of the robot tax in Russia, this idea grows more and more popular amid the mushrooming robotification of production processes. The main reason is that robots replace people in manufacturing ${ }^{4}$ but avoid an equivalent tax burden. It is believed to influence revenues of

\footnotetext{
${ }^{2}$ Nazarova A.A., Gubaidullina R.R. [Socio-economic aspects of robotification and information economy]. Matritsa nauchnogo poznaniya, 2017, no. 5, pp. 85-88. (In Russ.) URL: http://os-russia.com/SBORNIKI/MNP-2017-5.pdf

${ }^{3}$ The Robot That Takes Your Job Should Pay Taxes, says Bill Gates. URL: https://qz.com/911968/bill-gates-the-robot-that-takes-your-jobshould-pay-taxes/

${ }^{4}$ Ladanova E.O. [Will the robot's mind be able to substitute a human one completely?]. APRIORI. Seriya Estestvennye i tekhnicheskie nauki, 2015, no. 5, p. 15. (In Russ.) URL: http://apriori-journal.ru/seria2/52015/Ladanova.pdf
} 
the budgetary system of Russia that already undergoes hard times ${ }^{5}$. Anticipating the introduction of the robot tax, it seems reasonable to understand to what extent the robotification can influence the revenue from the existing taxes. Navigating through the tax system of the Russian Federation, we determine which taxes will be most affected by the robotification. It is worth mentioning that the robotification can have both a positive and negative effect on any tax ${ }^{6}$.

The automation of production processes frees up manpower, thus reducing the amount of social security charges. Furthermore, payroll funds also decrease since robots earn no wages. Remittances of the personal income tax fall as well.

The robotification may have an impact on indirect taxes. As the unemployment rises, personal income drops. It will undermine aggregate demand and subsequently retrench revenue from VAT and excise taxes.

However, the robotification can yet be favorable for the tax system ${ }^{7}$. Whereas entities cut their spending by introducing robots, their corporate profit increases alongside with income taxes they pay to the budget.

It cannot be overlooked that sales of robots will rise as more and more entities get interested in their use. So, it implies a growth in VAT remittances ${ }^{8}$. Moreover, value added of robots is much higher than those products redundant workers buy.

We build a model that primarily purports to show the robotification effect on tax revenue in Russia. We choose two taxes for analysis purposes, i.e.

\footnotetext{
${ }^{5}$ Roboty mogut zamenit' 50\% rabochei sily v Rossii [Robots may substitute 50 percent of human workforce in Russia].

URL: https://hightech.fm/2017/01/18/replacement (In Russ.)

${ }^{6}$ Lukashin Yu.P. [A man in the economics of the future]. MIRBIS Research Review, 2016, no. 1, pp. 17-33. (In Russ.)

${ }^{7}$ Bunto E.A. [Issues of robotifying the sectors of Russia's economy. Current situation and prospects]. Aktual'nye problemy i perspektivy razvitiya ekonomiki: rossiiskii i zarubezhnyi opyt = Current Issues and Prospects of Economic Development: Russian and Foreign Practices, 2016, no. 6, pp. 101-105. (In Russ.)

${ }^{8}$ If we consider the fact that the major part of the two taxes is paid to budgets of the constituent entities of the Russian Federation, then the robotification will mainly influence regional budgets. For the clarity of our idea, we use the expression the robotification effect/impact on the budget, without referring specifically to any constituent entity's budget, region's budget.
}

corporate income tax and personal income tax. The idea is that the robotification enables entities to hire fewer workers, thus reducing the total withholding tax remitted to the budget due to the lower payroll fund. On the other hand, a possible reduction in payroll expenses significantly lowers the cost. So, with other factors being equal, the taxable base for the income tax will grow. Drawing upon forecasts and estimates of such organizations and agencies as International Federation of Robotics (IFR), ABI Research, Russian Association of Robotics (RAR) and Russian State Statistics Service (Rosstat) (Table 1), we made our own estimates.

Figures in Table 1 are based on the following statistics. According to IFR (World Robotics 2015), in 2015, 340 robots were sold in Russia, with the total robot sales being $2,892^{\circ}$. For data extrapolation purposes, we use RAR's researches. As RAR reports, industrial robot sales in Russia incremented by 27 percent per annum from 2005 through 2015, while the growth was expected to accelerate up to 50 percent per annum, for the State got more focused on the industrial robotification and retrofitting of industrial processes at large enterprises ${ }^{10}$. Notwithstanding such tremendous pace, Russia has rather humdrum robotics in comparison with other countries ${ }^{11}$. According to IFR, for example, China's annual sales of industrial robots amount to 60,000 units (Japan: 30,000 units; USA: 27,000 units). According to $A B I$ Research, global sales of industrial robots are forecasted to triple by $2024^{12}$.

Afterwards we assess how the industrial robotification influences the tax revenue from withholding taxes (Table 2). As reported by the UN,

\footnotetext{
${ }^{9}$ Report, World Robotics 2015 Industrial Robots. URL: http://www.diag.uniroma1.it/ deluca/rob1_en/2015_WorldRobotics_Exe cSummary.pdf

World Robotics 2015 mentions that the robot density in Russia is two robots per 10,000 industrial workers. According to Rosstat, 14,460 thousand people are employed in the Russian manufacturing sector. Thus, we assess the total number of industrial robots - 2,892 units.

${ }^{10}$ World Robotics Report 2016. URL: https://ifr.org/ifr-pressreleases/news/world-robotics-report-2016

${ }^{11}$ Tolkachev S.A., Kulakov A.D. [Neoindustrialization as the new technotronic economy (by example of introducing robots to the US industry)]. Mir novoi ekonomiki = The World of New Economy, 2015, no. 4, pp. 69-76. (In Russ.)

${ }^{12}$ According to IFR, as of 2015 sales of industrial robots amounted to 300,000 units.
} 
about 25 percent of working people may lose their jobs by 2024 due to the robotification in Russia. The main reason is that robots are more industrious, sturdier and foolproof [7]. However, the indicator $(25 \%)$ is too overstated, as RAR believes ${ }^{13}$, since Russia's robot density level ${ }^{14}$ is almost 70 times as low as the average level worldwide. Hence, international organizations' estimates of the robotification intensity are not sufficiently corroborated with the real situation in Russia. Thus, we decide to use the lowered indicator of 10 percent instead of 20 percent reflecting the loss of workplaces.

Based on Rosstat's data stating that, in 2015, $14,460,000$ people were employed in the manufacturing sector of Russia and forecasting that $41,084-2,892=38,192$ new industrial robots will have been put into operation by 2024 , we figure out that one industrial robot is capable of substituting 37 workers in the manufacturing sector $([14,460,000 \times 0.1] / 38,192])$. Considering the information on the number of robots involved in the manufacturing sector by year, we computed the number of displaced workers on an accrual basis and the number of industrial workers in each year within the 2017-2024 span. Rosstat also reports the average monthly pay in the manufacturing sector, being equal to RUB 34,748 . Based on that, we assessed the accrued salary of an industrial worker for the year and the fiscal revenue loss as a product of the accrued wage and withholding tax rate (13\%).

At the following step of this mathematical model, we assess how the robotification influences the corporate income tax.

We shall concentrate on savings from human labor displacement. Considering the number of industrial workers (Table 2), we calculate to what extent their quantity will change year after year and determine how many workers will be made redundant. The resultant figures shall be multiplied by the annual accrued wage of an industrial worker, thus showing how much entities will save per year as a result of human labor displacement. Considering that depreciation and wages are attributed to

\footnotetext{
${ }^{13}$ Analytical researches of the Russian Association of Robotics. Global Robotics Market. URL: http://robotunion.ru/ru/analitika (In Russ.)

${ }^{14}$ The number of robots per 10,000 workers.
}

the cost of products, entities will get displacement savings net of depreciation charges, rather than the gross amount.

The taxable base of the income tax will increase since the cost will drop, thus generating marginal income to the budget as much as the product of the decreased cost and the income tax rate (20\%) (Table 3).

As the analysis shows, the robotification may affect the tax revenue in 2017 only. In subsequent periods, marginal income from the increased taxable base of the income tax will exceed the income loss from decreased remittances of the withholding tax (Table 4).

Based on average estimates, RUB 4.6 million in marginal income will presumably be remitted to the budget as a result of the robotification between 2017-2024. Furthermore, we shall mention positive trends in marginal income to the budget (Fig. 1).

This positive forecast of the robotification impact becomes more obscure in the light of the fact that the employer assesses social security charges to be paid in line with the accrued amount of wages. So, if the robotification cuts the total wages accrued in the nearest future, total social security charges fall as well (Table 5).

As we prove, the robotification does not have a direct adverse effect on the budget since an increase in the income tax base offsets lower tax revenue from a decrease in the withholding tax. However, the robotification may seriously affect budgets of the Pension Funds, Compulsory Medical Insurance Fund and Social Security Fund. The stability of the Pension Fund of the Russian Federation is at primary peril. Even now, when the robotification implications are not palpable so far, the Pension Fund balance remains questionable, with the budget deficit of 3.5 percent in 2016, being presumably caused by transfers to the Pension Fund. Under the circumstances, marginal income of the budget (Table 5) is not sufficient to offset such implications and cover increased transfers.

That is why, entities may be compelled to cease making social security charges on employees' wages and opt for, say, would-be income, which can be 
yielded on the introduction of a robot ${ }^{15}$, or depreciation charges on robots, so to alleviate the pressure on the budget of the Pension Fund ${ }^{16}$.

It raises the question whether the above automation processes are common for Russia? ${ }^{17}$ Shall Russia slow down the robotification speed and introduce the robot tax?

Let us refer to statistical data. According to International Federation of Robotics (IFR), about 2,900 industrial robots were totally installed in Russia by 2015. Fig. 2 showcases the way sales of industrial robots change over the period from 2005 through 2014. As seen in the graph, sales of industrial robots demonstrated a stable growth by about 20 percent a year within the 2010-2013 span. In 2013, sales hit their record high of 615 robots (a 34-percent increase as compared with 2012), but the indicator slumped by 52 percent down to 300 robots in 2014. Drastic changes in the foreign exchange rate triggered the situation.

It is reasonable to compare this indicator in Russia and other countries (Fig. 3) ${ }^{18}$.

As stated in IFR's analytical research, in 2015, only 340 industrial robots were sold in Russia, i.e. much less than in other countries. Hence, the robotics has just started to gain momentum in Russia [8]. Many authors reckon an additional tax may inhibit the process.

Aleksei Kudrin, a renowned public official from Russia, believes that the withholding tax on robots would mean the tax on the technological progress. Russia should move in the opposite direction and streamline the technological progress. The robotification makes profits of rapidly growing companies rise. Such profits should be used to support the displaced workers ${ }^{19}$.

Robot-driven unemployment is another topical issue. However, as seen in Fig. 4, Russia significantly lags behind other countries by a robot density level per 10,000 industrial workers. Therefore, we emphasize that rapid unemployment growth rates are not so probable in Russia [9].

We can conclude Russia makes the first steps in installing robots in production ${ }^{20}$. Thus, if the robot tax is adopted at the current stage, it will inhibit the robotification process and lead to undesired results.

In this article we evaluate how robotics influences tax remittances to the budget. As proved by the research, adverse effects of the robotification on the tax revenue will be seen in 2017 only. Marginal income from the increased income tax base will exceed the income loss from decreased remittances of the withholding tax later on. According to preliminary estimates, the robotification may yield RUB 4.6 billion in marginal income between 2017 and $2024[10,11]$.

Nevertheless, there is a risk that the robotification will exert serious pressure on budgets of the Pension Fund, Compulsory Medical Insurance Fund and Social Security Fund. Hence, there exists a broad array of issues to be resolved and subsequently mitigate possible risks and avoiding underpayments to extra-budgetary funds.

\footnotetext{
${ }^{15}$ The substance of the taxable base for this tax is a controversial issue. The global community has not reached any single and unanimous opinion on the matter yet.

${ }^{16}$ This option, by its nature, is similar to payroll expenses since it is also posted to the cost and can be qualified as a payment for using a robot in some production process.

${ }^{17}$ Askarov D.T., Bakytzhan D.A. [Economic aspects of the introduction of the concept of unmanned production]. Nauka bez granits = Science without Borders, 2017, no. 3, pp. 16-21. (In Russ.)

${ }^{18}$ Fedoseeva O.N. [Influence of the process production robotics unemployment]. Master's Journal, 2016, no. 2, pp. 612-617. (In Russ.)
} 
Table 1

Sales of industrial robots and their number in Russia (forecast), pcs

\begin{tabular}{lll}
\hline Year & Sales of robots, units & The number of robots on an accrual basis, units \\
\hline 2015 & 340 & 2,892 \\
\hline 2016 & 510 & 3,402 \\
\hline 2017 & 765 & 4,167 \\
\hline 2018 & 1,149 & 5,315 \\
\hline 2019 & 1,721 & 7,036 \\
\hline 2020 & 2,582 & 9,618 \\
\hline 2021 & 3,873 & 13,490 \\
\hline 2022 & 5,809 & 19,300 \\
\hline 2023 & 8,714 & 28,014 \\
\hline 2024 & 13,071 & 41,084 \\
\hline
\end{tabular}

Source: Authoring based on International Federation of Robotics (IFR) data

Table 2

Robotification effects in the industrial sector on the withholding tax remitted to the budget (forecast)

\begin{tabular}{llllll}
\hline Period & $\begin{array}{l}\text { The number of } \\
\text { robots on an accrual } \\
\text { basis, units }\end{array}$ & $\begin{array}{l}\text { The number of } \\
\text { displaced workers on } \\
\text { an accrual basis, } \\
\text { units }\end{array}$ & $\begin{array}{l}\text { The number of industrial } \\
\text { workers, people }\end{array}$ & $\begin{array}{l}\text { Industrial worker's wage } \\
\text { accrued for the year*, } \\
\text { RUB }\end{array}$ & Income loss, RUB \\
\hline 2017 & 4,167 & 157,767 & $14,302,233$ & 450,334 & $-1,695,637,126$ \\
\hline 2018 & 5,315 & 201,213 & $14,258,787$ & 486,361 & $-2,746,932,144$ \\
\hline 2019 & 7,036 & 266,381 & $14,193,619$ & 525,270 & $-4,450,030,073$ \\
\hline 2020 & 9,618 & 364,134 & $14,095,866$ & 567,291 & $-7,209,048,718$ \\
\hline 2021 & 13,490 & 510,763 & $13,949,237$ & 612,675 & $-11,678,658,923$ \\
\hline 2022 & 19,300 & 730,706 & $13,729,294$ & 661,689 & $-18,919,427,455$ \\
\hline 2023 & 28,013 & $1,060,622$ & $13,399,378$ & 714,624 & $-30,649,472,478$ \\
\hline 2024 & 41,084 & $1,555,494$ & $12,904,506$ & 771,793 & $-49,652,145,414$ \\
\hline
\end{tabular}

Note. *Wages were indexed by the average annual inflation rate of 8 percent every year for the period between 2008 and 2016.

Source:Authoring 
Table 3

Robotification effects in the industrial sector on the corporate income tax remitted to the budget (forecast)

\begin{tabular}{lllllll}
\hline Year & $\begin{array}{l}\text { The number of } \\
\text { robots on an } \\
\text { accrual basis, units }\end{array}$ & $\begin{array}{l}\text { Monetary value } \\
\text { of robots, } \\
\text { million RUB }\end{array}$ & $\begin{array}{l}\text { Depreciation per } \\
\text { year", million RUB }\end{array}$ & $\begin{array}{l}\text { Savings from } \\
\text { labor } \\
\text { displacement per } \\
\text { year, million RUB }\end{array}$ & $\begin{array}{l}\text { Cost reduction, million } \\
\text { RUB }\end{array}$ & $\begin{array}{l}\text { Marginal income, } \\
\text { million RUB }\end{array}$ \\
\hline 2017 & 4,167 & 41,670 & $5,208.75$ & $13,043.362$ & $7,834.612$ & $1,566.922$ \\
\hline 2018 & 5,315 & 53,145 & $6,643.125$ & $21,130.247$ & $14,487.122$ & $2,897.424$ \\
\hline 2019 & 7,036 & $70,357,5$ & $8,794.687$ & 34,231 & $25,436.313$ & $5,087.262$ \\
\hline 2020 & 9,618 & $96,176,25$ & $12,022.031$ & $55,454.22$ & $43,432.189$ & $8,686.437$ \\
\hline 2021 & 13,490 & $134,904.375$ & $16,863.046$ & $89,835.837$ & $72,972.791$ & $14,594.558$ \\
\hline 2022 & 19,300 & $192,996.562$ & $24,124.57$ & $145,534.057$ & $121,409.487$ & $24,281.897$ \\
\hline 2023 & 28,013 & $280,134.844$ & $35,016.855$ & $235,765.173$ & $200,748.317$ & $40,149.663$ \\
\hline 2024 & 41,084 & $410,842.266$ & $51,355.283$ & $381,939.580$ & $330,584.296$ & $66,116.859$ \\
\hline
\end{tabular}

Note. ${ }^{*}$ Estimated as if one industrial robot costs RUB 10 million; ${ }^{* *}$ Estimated with a straight-line method and based on the assumption that industrial robots pertain to the fifth depreciation group with the useful life of seven to ten years.

Source:Authoring

Table 4

Income loss/surplus income of the budget as a result of the industrial robotification (forecast)

\begin{tabular}{ll}
\hline Year & Income loss/marginal income of the budget, million RUB \\
\hline 2017 & -128.715 \\
\hline 2018 & 150.492 \\
\hline 2019 & 637.233 \\
\hline 2020 & $1,477.389$ \\
\hline 2021 & $2,915.899$ \\
\hline 2022 & $5,362.47$ \\
\hline 2023 & $9,500.191$ \\
\hline 2024 & $16,464.714$ \\
\hline
\end{tabular}

Source:Authoring

Table 5

Robotification effects on social security charges (forecast)

\begin{tabular}{lllll}
\hline Year & $\begin{array}{l}\text { The number of employees } \\
\text { replaced with robots, people }\end{array}$ & $\begin{array}{l}\text { Industrial worker's wages } \\
\text { accrued for the year, RUB }\end{array}$ & $\begin{array}{l}\text { Reduction in social security } \\
\text { charges*, million RUB }\end{array}$ & $\begin{array}{l}\text { Marginal income from } \\
\text { corporate income tax } \\
\text { million RUB }\end{array}$ \\
\hline 2017 & 28,964 & 450,334 & $-3,913.008$ & 782.602 \\
\hline 2018 & 43,446 & 486,361 & $-6,339.074$ & $1,267.815$ \\
\hline 2019 & 65,168 & 525,270 & $-10,269.3$ & $2,053.86$ \\
\hline 2020 & 97,753 & 567,291 & $-18,854.435$ & $3,770.887$ \\
\hline 2021 & 146,629 & 612,675 & $-30,544.185$ & $6,108.837$ \\
\hline 2022 & 219,943 & 661,689 & $-49,481.579$ & $9,896.316$ \\
\hline 2023 & 329,915 & 714,624 & $-80,160.159$ & $16,032.032$ \\
\hline 2024 & 494,873 & 771,793 & $-129,618.449$ & $25,923.69$ \\
\hline
\end{tabular}

Note. *Calculated as if the rate of compulsory pension contributions for the 2017-2019 period was 22 percent and 26 percent in subsequent period; ${ }^{* *}$ due to a reduction in expenses for the social security charges.

Source: Authoring

Please cite this article as: Kamaraeva E.Ya., Maksimov N.A., P'yanova M.V. On Tax Implications of the Robotification. Digest Finance, 2017, vol. 22, iss. 4, pp. 437-446. https://doi.org/10.24891/df.22.4.437 
Figure 1

Income loss/surplus income of the budget as a result of robotification (forecast), million RUB

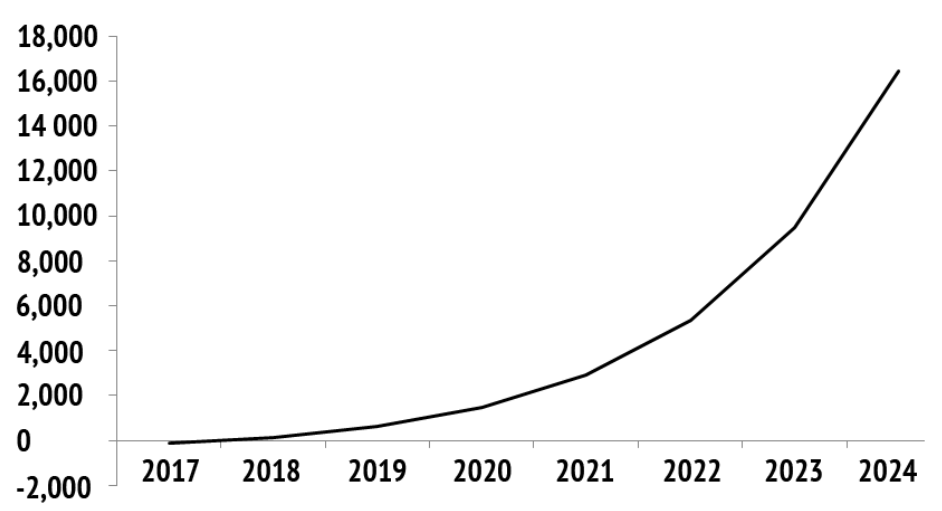

Source: Authoring

Figure 2

Trends in sales of industrial robots in the Russian Federation, 2005-2015, pcs

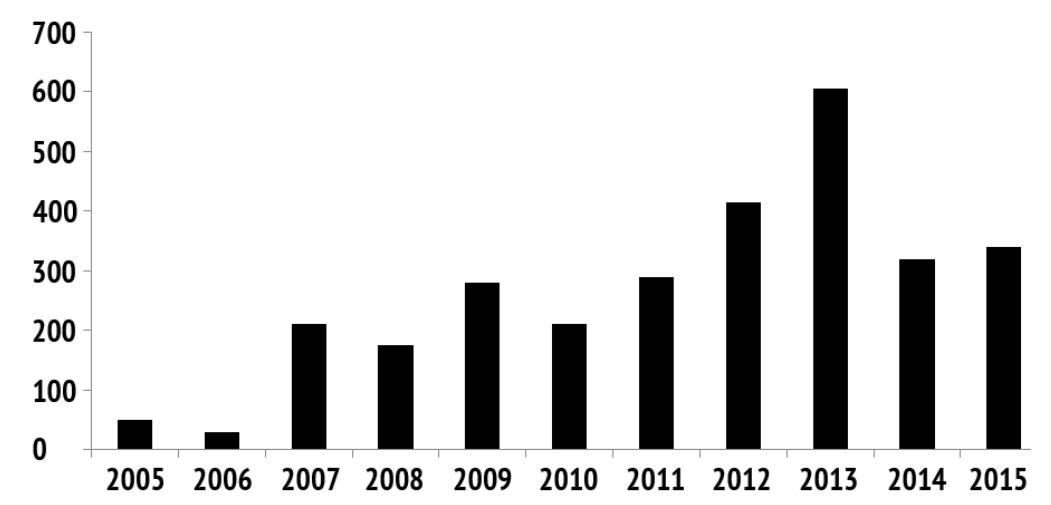

Source: Authoring based on International Federation of Robotics (IFR) data 
Figure 3

Sales of industrial robots in certain countries, 2015, pcs

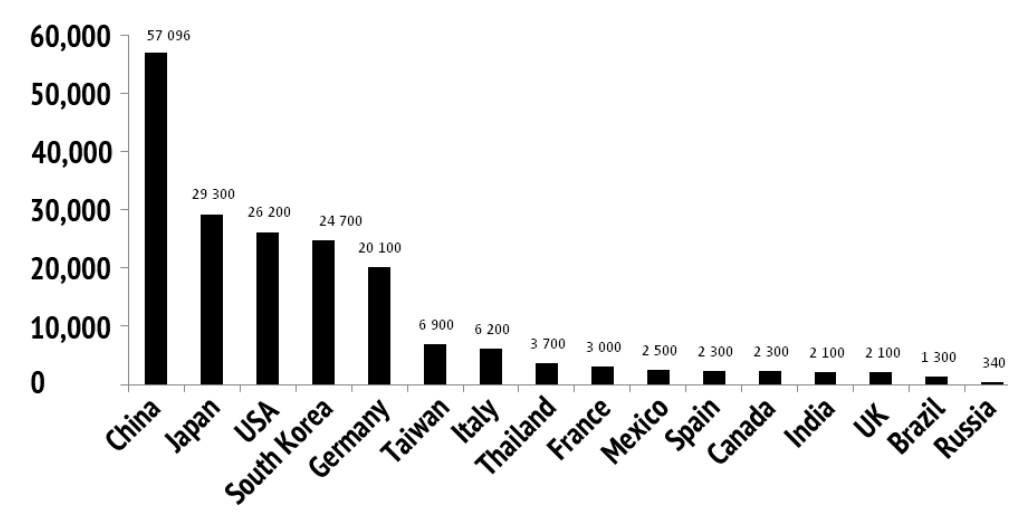

Source : Fedoseeva 0.N. [Influence of the process production robotics unemployment]. Master's Journal, 2016, no. 2, pp. 612-617. (In Russ.)

\section{Figure 4}

The number of industrial robots per 10,000 industrial workers, 2015, pcs

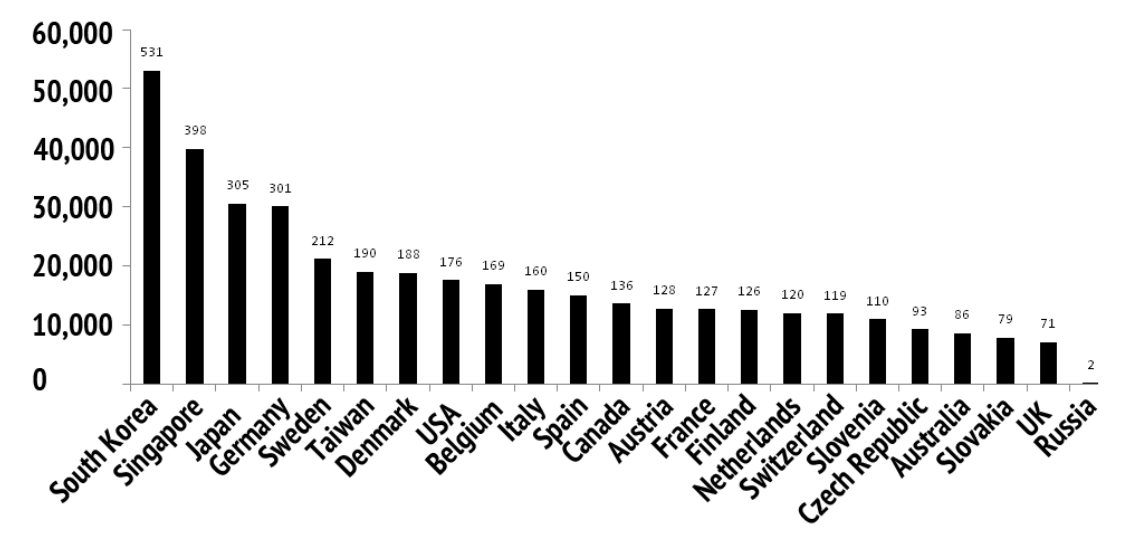

Source : [9]

\section{References}

1. Gadzhieva K.A., Zakharova M.A. Tax on Robots. In: Science and Education: Research and Development in the Era of Globalization. Materials of the I European International Research and Practice Conference. Vienna, Scientific Publishing Center Open Knowledge, 2017, pp. 59-65.

2. Kozlova O.A. [The socio-economic consequences of the robotization process or whether humanity will ever compete with robots]. Ekonomika i predprinimatel'stvo = Journal of Economy and Entrepreneurship, 2017, no. 3-1, pp. 1025-1028. (In Russ.)

3. P'yanova M.V., Lavnik R.V. [Investment in human capital development: tax issue]. Nalogi i finansy = Taxes and Finance, 2016, no. 3, pp. 20-34. (In Russ.)

4. Panskov V.G. [Tax policy and its impact on the labor market]. Finansy = Finance, 2017, no. 4, pp. 26-30. (In Russ.)

5. Yudina M.A. [Industry 4.0: Opportunities and Challenges]. Gosudarstvennoe upravlenie. Elektronnyi vestnik, 2017, no. 60, pp. 197-215. (In Russ.) 
URL: http://e-

journal.spa.msu.ru/uploads/vestnik/2017/vipusk_60._fevral_2017_g./problemi_upravlenija_teorija_i_prak tika/yudina.pdf

6. Maksyutina E.V. [The changing world of work: challenges of globalization]. $V$ mire nauchnykh otkrytii = In the World of Scientific Discoveries, 2014, no. 3-6, pp. 2345-2356. (In Russ.)

7. Kil'chukova A.L. [The labor market: Trends and prospects]. Izvestiya Kabardino-Balkarskogo nauchnogo tsentra RAN = Bulletin of the Kabardino-Balkar Scientific Center of the Russian Academy of Sciences, 2016, no. 6, pp. 160-165. (In Russ.)

8. Kolesnikov N.E., Kosheleva T.N. [Industrial robots and robotic complexes: Important components of high-performance workplaces in the Russian Federation]. Ekonomika $i$ upravlenie $=$ Economics and Management, 2014, no. 10, pp. 29-32. (In Russ.)

9. Kokhanov S.V. [Robotification of enterprises as a current trend in Russia's economy]. Molodye ekonomisty - budushchemu Rossii: materialy VIII mezhdunarodnoi nauchno-prakticheskoi konferentsii studentov $i$ molodykh uchenykh [Proc. 8th Int. Sci. Conf. Young Economists to the Future of Russia]. Stavropol, North Caucasus Federal University Publ., 2016, pp. 236-238.

10. P'yanova M.V., Lavnik R.V. [Tax instruments for encouraging investments into developing human capital]. Nalogi $\mathrm{i}$ nalogooblozhenie $=$ Taxes and Taxation, 2016, no. 10, pp. 768-778.

URL: https://doi.org/10.7256/1812-8688.2016.10.19607 (In Russ.)

11. Nagibina N.I., Shchukina A.A. [HR-Digital: Digital technologies in human resource management]. Internet-zhurnal Naukovedenie, 2017, vol. 9, no. 1, p. 24. URL: http://naukovedenie.ru/PDF/24EVN117.pdf (In Russ.)

\section{Conflict-of-interest notification}

We, the authors of this article, bindingly and explicitly declare of the partial and total lack of actual or potential conflict of interest with any other third party whatsoever, which may arise as a result of the publication of this article. This statement relates to the study, data collection and interpretation, writing and preparation of the article, and the decision to submit the manuscript for publication. 